\title{
The foundations of 'peace' as a value for the promotion of human rights in Africa
}

\author{
Nomthandazo Ntlama* \\ Associate Professor of Public Law, College of Law and Management Studies, \\ University of KwaZulu-Natal, South Africa
}

\begin{abstract}
Summary
This article identifies 'peace' as a strategic value in promoting human rights in Africa. The objective is to juxtapose the theoretical and practical foundations of 'peace' as a conceptual basis for the promotion of human rights into a substantive reality. The article does not examine the status of Africa's political context as such, an undertaking which will redirect the envisaged assumption of the stability of African governments in the regulation of state authority. The article is premised on the notion that such stability may provide a foundation for 'peace' as a value that is likely to create an environment conducive to greater respect for all human rights.
\end{abstract}

Key words: peace; value; strategic; foundation; human rights; Africa

\section{Introduction}

The promotion of human rights in Africa is seen against the background of their development within the framework of international human rights. ${ }^{1}$ This evolution of rights is owed to the struggles within African states in the colonial and post-independence eras. As a consequence, 'human rights have been elevated as a matter

* BJur LLB (Fort Hare) LLM (Stellenbosch) LLD (South Africa); Ntlama@ukzn.ac.za. Presented at the Beijing Forum on Human Rights Conference organised and published in conference proceedings by the China Society for Human Rights Studies, held on 16-17 September 2015 with the theme Peace and Development: Victory of World's Anti-Fascist War and Human Rights Advancement, Beijing, China.

1 A d'Amato 'The concept of human rights in international law' (1982) 82 Columbia Law Review 1110-1159. 
that deserves the attention of African governments and seen as a value that inform and inspire grass-roots approaches to them' ${ }^{2}$ The inspiration for their development is deduced from the quest to uphold the inherent values in human rights norms and standards that should represent a qualitatively higher form of unity and integration for the African continent. ${ }^{3}$ Their development paves the way for the integration of 'peace' as a central value in the general system of the rights framework in Africa. The integration of this value further offers an opportunity for the advancement of a regional perspective towards the establishment of a value-based approach for human rights in Africa. In essence, its integration seeks to ensure effective and responsible leadership and the empowerment of people to participate and bring inputs in the decision-making process through the system of human rights, which infuses 'peace' as a value. ${ }^{4}$ This approach is likely to create an environment that is conducive to the consolidation of the state's responsibilities by requiring legislative and other policyrelated programmes to provide a framework within which 'peace' may be consolidated as a foundational value in the realisation of human rights.

However, the realisation of human rights in Africa is thwarted by various challenges and atrocities that have an impact on the development of 'peace' as a value in the promotion and protection of human rights. These challenges relate to violence, ethnicity, corruption, disrespect for traditional value systems and other related factors, ${ }^{5}$ which factors threaten the stability of the African continent and the centrality of 'peace' as a value in the promotion of human rights in Africa.

Furthermore, the concept of 'peace' in developing a value-based approach in promoting human rights is unclear. The lack of certainty about this concept derives from the extent to which it may be used to ensure its substantive translation into specific human rights. The lack of clarity about the effect of 'peace' as a value derives from its 'indirect' application in the constitutional and legislative instruments that seek to protect human rights. This means that the concept of 'peace' is untethered from the interpretation of the various provisions in order to conceptualise the meaningful and effective promotion of human rights.

2 C Villa-Vicencio 'Transitional justice and human rights in Africa' in J Diescho \& A Bösl (eds) Human rights in Africa: Legal perspectives on their protection and promotion (2009) 48.

3 B Gawanas 'The African Union: Concepts and implementation mechanisms relating to human rights' in Diescho \& Bosl (n 2 above) 139.

4 W Huber 'Human rights and globalisation - Are human rights a "Western" concept or a universality principle?' (2014) 55 Ned Geref Teologiese Tydskrif 117-137 http://ngtt.co.za (accessed 25 July 2015).

5 PD Williams 'Enhancing civilian protection in peace operations: Insights from Africa' (2010) Africa Centre for Strategic Studies Research Paper 1 https://www. polity.co.uk/up2/pdf/ACSS_Research_Paper1_Civilian_Protection_PKOs_Sept2010. pdf (accessed 23 July 2015). 
Against this background, the article identifies 'peace' as a strategic value in promoting human rights in Africa. The objective is to juxtapose the theoretical and practical foundations of 'peace' as a conceptual basis for the promotion of human rights into a substantive reality. The article does not examine the status of Africa's political context because such an undertaking will redirect the envisaged assumption of the stability of African governments in the regulation of state authority. The article is premised on the notion that such stability may provide a foundation for 'peace' as a value that is likely to create an environment conducive to a greater respect for all human rights. The likelihood is traced from the potential of 'peace' to develop a value-based approach, which concretises the argument for its use as a strategic value for the advancement of human rights. The article acknowledges the challenges faced by African governments which impact negatively on the evolution of human rights, as noted above. However, these challenges are not the subject of this inquiry.

\section{Peace: Value-based strategy for human rights?}

\subsection{Elements of the value-based approach to human rights}

Africa is faced with the pressing need to ensure the meaningful integration of 'peace' as a value for the promotion of human rights. Human rights may be defined in terms of rights that impose positive or negative obligations on states. This means that these rights are designed within the framework of the agreed norms, values and standards that regulate the conduct of states towards their citizens in both the public and private spheres. Without classifying these rights, the Universal Declaration of Human Rights (Universal Declaration), ${ }^{6}$ notwithstanding its non-binding status on states, is the primary document that provides a conceptual framework for the globalisation of human rights. On the African continent, the African Charter on Human and Peoples' Rights (African Charter) ${ }^{7}$ is the document that conceptualises human rights as inherent and inalienable rights guaranteed to everyone by virtue of being human, and which cannot be taken away, whether by the state or private individuals. These instruments may be indirectly interpreted to include a framework for the linkage of 'peace' in the affirmation of the rights framework. 'Peace' is defined as a moral compass that seeks to ensure a 'sense of security and safety and harmonious relationships, without feeling a

6 Adopted on 10 December in 1948. The Universal Declaration was supplemented by the International Covenant on Civil and Political Rights (ICCPR), adopted by the UN General Assembly on 16 December 1966 and entered into force 23 March 1976, and the International Covenant on Economic, Social and Cultural Rights (ICESCR), which was also adopted on 16 December 1966 and entered into force on 3 January 1976. Together these instruments are referred to as the International Bill of Human Rights.

7 Adopted in Nairobi, Kenya, on 27 June 1981 and entered into force on 21 October 21. 
need for revenge, punishment, reparations, or apologies. It is a sense of goodwill and well-being. ${ }^{\prime 8}$ This definition was qualified by Premier Zhou Enlai of China on 31 December 1953 when he developed the five basic elements which entail the concept of 'peace' as mutual respect for each nation's territorial integrity and sovereignty; nonaggression; non-interference in each other's internal affairs; equality and mutual benefit; and peaceful co-existence. ${ }^{9}$

These elements relate to the purpose of the United Nations (UN) Charter, ${ }^{10}$ as envisaged in article 1 which provides:

(1) to maintain international peace and security, and to that end, to take effective collective measures for the prevention and removal of threats to the peace, and for the suppression of acts of aggression or other breaches of the peace, and to bring about by peaceful means, and in conformity with the principles of justice and international law, adjustment or settlement of international disputes or situations which might lead to a breach of the peace; and

(2) to develop friendly relations among nations based on respect for the principle of equal rights and self-determination of peoples, and to take other appropriate measures to strengthen universal peace.

Although these principles focus more on the relationship between states, they provide the frame of reference for the use of 'peace' as a value for human rights promotion between a state and its citizens at the domestic level. Harmonious relations between states have the potential to contribute to the way in which they adhere to the prescripts of international human rights in the advancement not only of the respect, protection and promotion but also the fulfilment of the rights at domestic level. ${ }^{11}$

In the African context, the Constitutive Act of the African Union $(\mathrm{AU})^{12}$ endorses the concept of 'peace' and determines to 'promote and protect human and peoples' rights, consolidate democratic institutions and culture, and to ensure good governance and the rule of law'. ${ }^{13}$ Of great significance is article 4(h), which entrenches the protection of civilians from genocide, war crimes and crimes against humanity through military intervention by member states. This article is further characterised by ${ }^{14}$

the respect for democratic principles, human rights, the rule of law and good governance ... the sanctity of human life, condemnation and

8 http://www.cppi.co/2-principle-of-peace.html (accessed 25 July 2015).

9 As above.

10 Signed on 26 June 1945 in San Francisco and came into force on 24 October 1945 (my emphasis).

11 See, eg, the requirements of sec 7(2) of the Constitution of the Republic of South Africa, 1996, which obligates the state to ensure the enjoyment of human rights by ensuring their fulfilment.

12 Adopted in 2000 at the Lomé Summit (Togo) and entered into force in 2001.

13 See the Preamble.

14 See arts $4(m) \&(0)$. 
rejection of impunity and political assassination, acts of terrorism and subversive activities.

This commitment is a 'source of redress and as a standard by which to measure the reasonableness of the promotion of human rights'. ${ }^{15}$ The significance of 'peace' in the Constitutive Act is supplemented by article 11 of the African Charter on Democracy, Elections and Good Governance, ${ }^{16}$ as state parties are obligated to 'develop the necessary legislative and policy frameworks to establish and strengthen a culture of democracy and peace'. Reardon asserts that the affirmation of 'peace' is a legitimate commitment that embraces its infusion into the rights domain as a framework that ${ }^{17}$

- $\quad$ offers lively and effective means to develop the capacity to be human and prepare citizens to devise and engage on the debates of human rights promotion;

- $\quad$ is integral to human rights that without peace, there is a lack of the primary component of their core and essential substance;

- is the essence and arbiter of human rights, antithesis of violence, touching on multiple and complex aspects of human experience;

- $\quad$ is a means to cultivate transformational thinking which lies in viewing human rights norms and standards as integrated ethical system;

- $\quad$ is the sum and ethos of the values and principles of human rights taken as a whole is or would be - peace;

- $\quad$ is the specific indicator and a particular measure of progress towards the substantive translation of human rights into reality;

- $\quad$ puts flesh on the bones of the abstraction of human rights and provides details of how to bring the flesh to life.

These principles are essential for the justifiability of 'peace' as a value in the general system of human rights in Africa, considering the historical context in which these rights were used as a justification in the struggle against colonialism, a system which had no respect for these rights. The Constitutive Act of the AU, for example, endorses the assertion and acknowledges the role of human rights in the struggle against colonialism. The acknowledgment is based on the following fundamental principles envisaged in its Preamble, as the Act recalls, first, the heroic struggles waged by our peoples and our countries for political independence, human dignity and economic emancipation. Second, it considers the Organization of African Unity (OAU) since its inception and the role it has played in the liberation and the attainment of the unity of our continent and a unique framework it has provided for our collective action in Africa and in our relations with the rest of the world; ${ }^{18}$ and third, its determination to promote and protect human and peoples' rights, consolidate democratic

15 J Dugard International law: A South African perspective (2010) 25.

16 Adopted on 30 January 2007 and entered into force on 15 February 2012, https:// www.au.int/en/treaties/african-charter-democracy-elections-and-governance (accessed 11 April 2017).

17 BA Reardon 'Human rights learning: Pedagogies and politics of peace' lecture delivered for the UNESCO Chair for Peace Education Master Conference at the University of Puerto Rico, 15 April 2009.

18 See Preamble of the Constitutive Act. 
institutions and culture, and to ensure good governance and the rule of law. ${ }^{19}$

It is in this context that the discourse of human rights cannot be undertaken in isolation from its historical context in Africa. The history is essential in evaluating the various strategies and methodologies that may strengthen a comprehensive and integrated approach in ensuring respect for all human rights. ${ }^{20}$ In a nutshell, this history enables $^{21}$

the acquiring of the capacity to restore and recall the legal encounters of the state with social reality, to learn from them and modify their own functioning in order to enhance their own self-awareness and ability to assimilate past experiences.

\subsection{Peace: Discourse of the value-based approach to human rights}

The discourse of human rights is clouded by what appears to be a legalistic approach that has been adopted by African governments in the promotion of these rights. An inflexible approach to the evolution of the principles of human rights, for example, is characterised, first, by the rules that highlight the need to legally recognise human rights and to institutionalise their respect through the adoption of various instruments. Second, an inflexible approach manifests itself in the structures and institutions, which relate to the structural divisions of powers and resources in society and mechanisms that exist to handle conflicts that may arise in this regard. Third, this approach is characterised by the relationships which refer to the relevance of rights for organising and governing the interaction between state and citizens, and amongst individuals and groups in society. Lastly, an inflexibility in approach appears from processes that underscore the importance of aiming for legitimacy and sustainability by taking care of how issues of access, protection and identity are addressed, paying attention to dignity, participation, inclusion, protection and accountability. ${ }^{22}$ This approach, for example, is evident in the inclusion of 'peace' as a right in the Protocol to the African Charter on Human and Peoples' Rights on the Rights of Women in Africa (African Women's Protocol). ${ }^{23}$ Article 10 of this Protocol guarantees women a

19 As above.

20 B Hart \& M Saed 'Integrating principles and practices of customary law: Conflict transformation, and restorative justice in Somaliland' (2010) 3 Africa Peace and Conflict Journal 1.

21 BM Zupančič 'Constitutional law and the jurisprudence of the European Court of Human Rights: An attempt at a synthesis' (2003) 1 Journal of Constitutional Law and Philosophy of Law 58.

22 M Parlevliet 'Conflict prevention in Africa: A matter of containment or change? The role of civil society in preventing deadly conflict in Africa' in E Sidiropoulos (ed) A continent apart: Kosovo, Africa and humanitarian intervention (2001) 61, quoted in V Dudouet \& B Schmelzle (eds) Human rights and conflict transformation: The challenges of just peace (2010).

23 Adopted by the African Union on 11 July 2003, Maputo, Mozambique. 
peaceful existence and the right to participate in the promotion and maintenance of peace. For their part, states are required to take all appropriate measures to ensure the increased participation of women:

(a) in programmes of education for peace and a culture of peace;

(b) in the structures and processes for conflict prevention, management and resolution at local, national, regional, continental and international levels;

(c) in the local, national, regional, continental and international decisionmaking structures to ensure physical, psychological, social and legal protection of asylum seekers, refugees, returnees and displaced persons, in particular women;

(d) in all levels of the structures established for the management of camps and settlements for asylum seekers, refugees, returnees and displaced persons, in particular, women.

This reference is a consolidation of the argument in the article that the above factors and their linkage to article 10 indicates their limitation in deepening the approach in advancing human rights because of a diminished emphasis on institutional and structural conditions which are pivotal in highlighting the protracted socio-political ills that bedevil post-colonial Africa. African states have not infused the values that are attached to the rights to ensure their sufficiency in the broader conceptualisation of all the rights. This conclusion is drawn from the non-inclusion of 'peace' as a value in the African Women's Protocol, and including other African instruments that seek to protect and promote human rights. ${ }^{24}$ The significance of 'peace' is indirectly unearthed in the application and interpretation of various provisions of these instruments as interpreted by the courts. ${ }^{25}$ The indirect application is also subject to interpretation by various scholars on the impact of a particular judgment on human rights promotion. ${ }^{26}$

The infusion of 'peace' as a foundational value in the promotion of human rights in Africa, as affirmed by Goonesekere, ${ }^{27}$ involves the analysis of the challenges from a holistic perspective of human rights and related obligations of states; the development of steps that have to be taken to ensure the implementation of the identified rights and how they can be supported and facilitated by mutual co-operation; the establishment of the mechanisms to monitor the implementation of rights in recognition of the fact that human rights are not necessarily through the legalistic approach that they have to be enforced; and the participation of civil society with a view to making a

24 See eg the African Charter.

25 L Michael 'Jurisprudential analysis of the African Court on Human and Peoples' Rights: From 2004 to 2010' (2012) African Yearbook of International Law 1.

26 R Cole 'The emerging jurisprudence of the African Court on Human and Peoples' Rights - African Commission on Human and Peoples' Rights v Great Socialist Peoples' Libyan Arab Jamahiriya (order for provisional measures)' (2012) 14 University of Botswana Law Journal 147.

27 S Goonesekere 'A rights-based approach to realising gender equality' http:// www.un.org/womenwatch/daw/news/savitri.htm (accessed 28 July 2015). 
difference in the decision-making process. ${ }^{28}$ These principles denote the several strengths of the value-based approach, which include the establishment of specific government accountability in promoting peace; addressing a broad range of legal, socio-political and cultural determinants of peace; the emphasis on the importance of setting specific goals and targets for the achievement of human rights; the monitoring and evaluation of the progress made towards the achievement of human rights; insistence on good governance; and stressing the need for transparency and participation in efforts to secure human rights. 29

This provision of a value-based approach underpins 'peace' as a value which can serve as a vehicle for unity, solidarity and peace, as well as an instrument for democracy and sustainable development which the vision of the region should encompass in order to eliminate the various factors that may compromise the promotion and protection of all human rights. Such elimination has the potential to ensure balancing human and sustainable development, the protection of the environment and integration of the contemporary and traditional humanistic values. ${ }^{30}$ It epitomises the particular standards that are built into the rights framework concerning the historical, civilisational, cultural and semantic connotations in the broader framework of human rights. ${ }^{31}$

The importance of 'peace' as a value in human rights promotion indirectly derives from article 29(1) of the African Charter, which traces the foundations of 'peace' in family structures by endorsing the duty of the person, as it provides that the individual shall also have the duty to 'preserve the harmonious development of the family and to work for the cohesion and respect of the family; to respect his parents at all times, to maintain them in case of need'. Article 29 further provides for individual duties to:

(4) preserve and strengthen social and national solidarity, particularly when the latter is threatened;

(5) preserve and strengthen the national independence and the territorial integrity of his country and to contribute to its defence in accordance with the law;

(7) preserve and strengthen positive African cultural values in his relations with other members of the society, in the spirit of tolerance, dialogue and consultation and, in general, to contribute to the promotion of the moral well-being of society; and

(8) contribute to the best of his abilities, at all times and at all levels, to the promotion and achievement of African unity.

28 As above.

29 A Chapman 'The foundations of a human right to health: Human rights and bioethics in dialogue' (2015) 17 Health and Human Rights Journal 2.

30 UNESCO 'Learning to live together in peace and harmony: Values education for peace, human rights, democracy and sustainable development for the Asia-Pacific region' (1998) http://unesdoc.unesco.org/images/0011/001143/114357eo.pdf (accessed 23 July 2015).

31 Zupančič (n 21 above). 
The individual duties are an endorsement of a broader approach to human rights promotion, which should not be limited to legalistic approaches of the rights framework but be inclusive of other values that may enhance the development of a process that is sustainable. The interaction of the two (rights and values) is important for any sustainable development that may yield positive results for the advancement of 'peace' as a value in human rights protection. Goonesekere argues that the essence of the interaction of rights and values reinforces the language of 'peace' as a legitimate claim to be articulated with moral authority which other approaches lack. Second, he asserts that the interrelationship of rights and values is a language which is recognised by the powerful and which stimulates in many deep chords of response. ${ }^{32}$ Third, the interdependence has the potential to empower individuals and communities at grassroots level on the importance of human rights. These factors are further qualified by the genuineness of the value approach as an important goal in itself. ${ }^{33}$

The integration of the two (rights and values) concretises an argument for the advancement of Africa in ${ }^{34}$

building on its own foundations and ensure that there is much to be learned from the continent about leading a good and harmonious life, taking care of each other, respect the wisdom of older people and being one with nature and spiritual world.

These principles are essential for the legitimacy of 'peace' as a founding value for the promotion of human rights. The affirmation of 'peace' is qualified by its flexibility and the reference to the eternal values and principles of fairness, equity, justice, reasonableness and good faith in light of the public interest which should conform to the basic values of the various instruments that Africa has developed in the promotion of human rights. ${ }^{35}$

However, and as mentioned above, Africa faces various challenges that have a direct impact on the promotion of human rights. ${ }^{36}$ These challenges further lead to a minimalistic approach in the development of various approaches to the evolution of a system of human rights. ${ }^{37}$ They threaten the centrality of 'peace' as a value in the general system of human rights in Africa. As mentioned before, the intention in the article is not to examine Africa's political context but to acknowledge

\footnotetext{
32 Goonesekere (n 27 above).

33 As above.

34 B Brock-Utne 'Peace research with a diversity perspective: A look to Africa' http:// www.gmu.edu/programs/icar/ijps/vol9_2/Brock-Utne_92IJPS.pdf (accessed 25 July 2015).

35 See 'Foreword' by DH van Zyl in J Church et al Human rights from a comparative and international perspective (2007).

36 E Baimu 'The African Union: Hope for better protection of human rights in Africa?' (2001) 1 African Human Rights Law Journal 299.

37 TF Yerima 'Comparative evaluation of the challenges of African regional human rights courts' (2011) 4 Journal of Politics and Law 1.
} 
by way of the example of the recent wave of attacks against black people of foreign origin in South Africa, the clear evidence of the challenges faced by Africa. The underlying causes of these attacks, allegedly indirectly, are driven by the quest for the promotion of human rights. ${ }^{38}$ There is a contestation between the locals and foreign nationals over the socio-economic space, the resolution of which is essential for devising mechanisms that will assist in the determination and articulation of what constitutes the value of 'peace' in human rights promotion.

These challenges are further evident in the instability encountered in Lesotho, a member state of the Southern African Development Community (SADC). Lesotho has not been politically stable since the attempted coup on 21 August 2014. Lesotho was forced into early elections in February 2015, a situation in which the SADC played a significant role and deployed the Deputy-President of the Republic of South Africa. ${ }^{39}$ Briefly, Lesotho was plunged back into turmoil after the elections with the resultant death of Lieutenant-General Maaparankoe Mahao, who allegedly was brutally murdered by soldiers that were sent to arrest him on suspicion of being the mutiny leader. ${ }^{40}$ South Africa, previously viewed as a leading democracy in Africa, is at a constitutional crossroads amid calls for the resignation of President Zuma following the reshuffling of the cabinet and the dismissal of Minister of Finance and his deputy. A motion of no confidence in the President has been tabled in parliament and demands for his removal from office which are traceable to his association with the Gupta family, who are regarded as controlling the President in respect of the way in which the country is run. ${ }^{41}$

Notwithstanding Africa's challenges, which directly or indirectly are linked and attributed to the general failure of political leadership in Africa, of further and greater concern is the role of the West and especially of the United States of America (USA) in Africa's affairs. This role amounts to interference that relegates the role of the $A U$ to a sphere without international significance on matters that affect the continent as a result of the financial clout of the USA. This

38 G Maina et al 'It's not just xenophobia' 29 March 2011 http://www.accord.org.za/ publication/its-not-just-xenophobia/ (accessed 11 April 2017).

39 T Simelane 'Watch: Lesotho PM refutes political instability' 17 June 2015 http:// www.enca.com/africa/watch-lesotho-pm-refutes-political-instability (accessed 3 August 2015).

40 S Hofstatter \& K Sutherland 'Lesotho general told of death plot' 6 July 2015 http:// www.timeslive.co.za/thetimes/2015/07/06/Lesotho-general-told-of-death-plot (accessed 4 August 2015).

41 See Public Protector Report entitled 'State capture: Investigation into alleged improper and unethical conduct by the President and other state functionaries relating to alleged improper relationships and involvement of the Gupta family in the removal and appointment of Ministers and directors of state-owned enterprises resulting in improper and possibly corrupt award of state contracts and benefits to the Gupta family businesses' No 6 of 2016/2017, http://www. da.org.za/wp-content/uploads/2016/11/State-of-Capture-14-October-2016.pdf (accessed 12 April 2017). 
involvement raises the question whether the promotion of fundamental values within the framework of 'peace' is subject to the economic and political power of the USA: How does Africa use 'peace' as a value in the promotion of human rights if the undertaking is clouded by the economic and political exploitation of Africa's situation? This question is inspired by how the USA, at times, prescribes how African countries should solve their problems, as if they do not have their own political and economic 'home': the African Union. The AU has its shortcomings, which are not the subject of the article, but it is better placed to devise some mediating and consensus-seeking measures that have the potential to produce lasting political solutions rather than the imposition of Western ideology in resolving Africa's challenges. ${ }^{42}$

The strategic diplomacy of the $A U$ in addressing Africa's problems in ensuring the preservation and upholding of stability in African countries, at face value and on assumption herein, directly harnesses the argument in the article for 'peace' as a fundamental strategy for human rights protection. The involvement of the $A U$ in African countries does not mean interference in the regulation of their internal affairs but the rejection of dictatorship; it does not adopt a 'silent rule' and does not criticise a particular state in respect of the way in which it upholds the protection of the rights of its citizens. ${ }^{43}$ The establishment of the Peace and Security Council ${ }^{44}$ (PSC) of the $\mathrm{AU}$ as a standing decision-making body responsible for the maintenance of continental peace and security is indicative of Africa's advances in promoting 'peace' in Africa which does not need a 'remote-control approach' from Westerners. The principle of noninterference is linked directly to sovereignty, by which state parties respect the independence of each other in the regulation of their internal authorities, subject to the prescribed minimum standards as required by national and international laws. ${ }^{45}$ 'Sovereignty', in essence, is defined as a 'legal status from which certain legal consequences, in particular rights, being intertwined with obligations, are derived'. ${ }^{46}$ Peters argues that the 'status is limited by human

42 'African Union will not observe elections in Burundi' http://www.aljazeera.com/ news/2015/06/african-union-observe-elections-burundi-150628172409440.html (accessed 31 July 2015).

$43 \mathrm{M}$ Wood 'Non-intervention (non-interference in domestic affairs)' https://pesd. princeton.edu/?q=node/258 (accessed 4 May 2016).

44 See Protocol Relating to the Establishment of the Peace and Security Council of the $\mathrm{AU}$, adopted in Durban, South Africa, and entered into force on 26 December 2003, http://www.peaceau.org/en/page/38-peace-and-security-council\#sthash.IY giVNjZ.dpuf (accessed 11 April 2017).

45 A Benoist What is sovereignty? (1999) 101 http://www2.congreso.gob.pe/sicr/ cendocbib/con2_uibd.nsf/A20317BBCECF9E1E0525770A00586F60/\$FILE/what. pdf (accessed 12 April 2017).

46 A Peters 'Humanity as the $A$ and $\Omega$ of sovereignty' (2009) 20 European Journal of International Law 514. 
rights because it is from the outset determined and qualified by humanity and has a legal value to the extent that it respects human rights, interests and thus needs'. 47 The upholding of the intersection of the principles of non-interference and sovereignty has the potential to cause a widespread migration of refugees in search of security and the protection of their rights. ${ }^{48}$ In turn, this is likely to have an impact that threatens the prospects of 'peace' as foundational to security and to its successful integration in the domestic framework of the law.

It is acknowledged that Africa falls within the framework of the community of nations. However, the constant interference by the West in Africa's domestic affairs undermines the ability and skill of African leaders to resolve Africa's issues in a manner befitting the continent. The instruments that so far have been adopted, the established institutions and the way in which the AU has handled some of the problematic situations in Africa shows an awareness of Africa's wavering support for the advancement of 'peace' as a value that has the potential to promote human rights. The Libyan crisis in 2011, which could have plunged the continent into turmoil, is one of the few examples where the AU showed collective responsibility and leadership in handling the situation without interference by Western countries. Africa has the potential, on its own, to establish harmonious relationships that are likely to affirm the value-based approach of 'peace' in the protection and promotion of human rights. In turn, this potential envisions the argument in the article for the use of 'peace' as a strategic foundational value for the promotion of human rights.

\section{Conclusion}

The article argues that Africa is faced with a pressing need to integrate 'peace' as a value into the domain of human rights protection on the continent. The integration of 'peace' as a value and a right is a strategic direction in the establishment of harmonious relations among African countries torn by conflict and violence which, in turn, compromise the promotion of human rights. The article, therefore, points out that it is evident and possible that 'peace' should be adopted as a strategic value that may be infused into the rights framework. Its elements provide a foundation within which Africa can aspire to succeed. Notwithstanding the various challenges faced by Africa, the value-based approach of 'peace' has the potential to promote a legalistic and rigid framework in the promotion of human rights. As matters now stand, 'peace' is indirectly applied as a value in the interpretation of the provisions of the various instruments Africa adopted in order to address the socio-political ills it faces. However,

\footnotetext{
47 As above.

48 Eg, President Robert Mugabe has constantly objected to the critiques in respect of the way in which fundamental rights were being undermined in Zimbabwe, leading to the migration of his citizens for better opportunities.
} 
there is still an opportunity for the integration of 'peace' as a value in the broader rights framework. 